\title{
Studies on the Plasma 17-hydroxycorticosteroids Levels in Normal Pregnant Women and Neonatal Period
}

\author{
Kenichi WASEDA \\ Department of Obstetrics and Gynecology, School of Medicine, The University of \\ Kanazawa, Kanazawa, Japan (Director : Professor Fumio Akasu, M.D., Ph.D.)
}

Most studies revealed that the urinary 17-hydroxycorticosteroids (17-OHCS) excretion increases considerably with advancing pregnancy, but there exists much controversy as to the blood levels of 17-OHCS in pregnant women.

In this experiment the blood levels of 17-OHCS were determined by the Peterson et al. modified method.

In the field of obstetrics and gynecology, adrenals are said to be the third sexaul gland by some workers. But the studies on the plasma 17-OHCS are scanty. Therefore the author researched the changes of plasma 17-OHCS levels in this field, for example, the diurnal variation in normal non-pregnant women, changes of menstrual cycle, pregnancy, labor, and cord plasma. Changes of plasma 17-OHCS levels following administration of ACTH 25 i.u. and of estradiol benzoate in a single dose of $5 \mathrm{mg}$. to normal pregnant women and then variation of plasma 17-OHCS levels of castrated females following administration of pregnant mare serum gonadotropin (PMS-G) in doses of 4000 i.u. or 6000 i.u., also estradiol benzoate in a single dose of $2 \mathrm{mg}$. were also investigated.

The results of these experiments are summarized as follows.

1) In the standard curve, extinction coefficient and average optical density at various wave lengths of Porter-Silber chromogen: The standard solution of $5 \mu \mathrm{g}$./dl. hydrocortisone and extracted plasma $5 \mathrm{ml}$. were measured for absorbance at every wave length from 400 to $450 \mathrm{~m} \mu$, and it showed the maximal absorption at $410 \mathrm{~m} \mu$. Extinction coefficients of standard concentration 1, 2, and $5 \mu \mathrm{g}$ per $5 \mathrm{ml}$. hydrocortisone were a little different among each group, but in the same group of standard curve the slope indicated an absolutely straight line.

2) Diurnal variation of plasma 17-OHCS levels were tested in healthy non-pregnant women. Blood samplings were taken three times daily from the cubital vein. The highest plasma 17-OHCS value was observed in the early morning specimens, afternoon specimens showed lowered value and the night specimens showed the least value.

3) Changes of plasma 17-OHCS levels in menstrual cycle of healthy non-pregnant women: Changes of urinary 17-OHCS excretions during menstrual cycles have been observed by many investigators, but those in the plasma have scarcely been observed. Socalled ovulation peak (16.2 $\pm 1.24 \mu \mathrm{g}$./dl.) was observed in plasma 17-OHCS as in the case of estrogen. Before and after ovulation slight falls in plasma 17-OHCS were observed 
(in follicular phase $11.3 \pm 1.69 \mu \mathrm{g} . / \mathrm{dl}$., in luteal phase $10.5 \pm 1.50 \mu \mathrm{g} . / \mathrm{dl}$.)

Following administration of PMS-G or estradiol benzoate the plasma 17-OHCS levels of castrated females elevated. Hence the ovulation peak might probably be caused by the highest secretion of gonadotropin or estrogen.

4) The levels of plasma total 17-OHCS of normal pregnant females: The plasma 17-OHCS concentrations increased remarkably with advancing pregnancy, and in the last trimester the levels were approximately two or three times those in normal non-pregnant females. In the parturition a further rise occurred. This rise in the parturition may probably be ascribed to the increased labor stress of the maternal body. The mean value of 17-OHCS of primipara was $62.0 \pm 9.51 \mu \mathrm{g}$./dl., while that of multipara was $42.5 \pm 4.62 \mu \mathrm{g}$./ dl., Mean cordal plasma level of the former was $24.0 \pm 4.16 \mu \mathrm{g} . / \mathrm{dl}$. and that of the latter $17.9 \pm 5.96 \mu \mathrm{g} . / \mathrm{dl} . . \quad$ In spite of the high plasma 17-OHCS level there are no remarked clinical signs of hypercorticalism in pregnancy, probably because of the binding of most of the plasma cortisol with globulin in pregnancy. The lower values of cordal plasma may be due to the selective placental transfer of 17-OHCS or to a dissociation of 17-OHCS by the fetal and placental tissues.

5) Effects of the administration of ACTH or estradiol benzoate on the plasma 17OHCS values of pregnant women : Following administration of ACTH or estradiol benzoate the 17-OHCS concentrations elevated. The elevated concentration by ACTH administration might be ascribed to the rise of cortisol-binding globulin.

(pp. 1207〜1221) 


\title{
妊婦並びそ新生児血中 $17-$ Hydroxycorticosteroids
}

\author{
值に関する 研究 \\ 金沢大学医学部産科婦人科学教室（指導 赤須文男教授）
}

早稲田健一

(昭和 43 年 4 月 5 日受付)

\begin{abstract}
妊娠時の尿中 17-OHCS 亿ついては増量するとなす多くの報告をみるが血墏中のものについては詳ら かではない. 我々の Peterson らの方法の成績では, 弤娠月数の進むと共に血漿 17-OHCS は増量し,

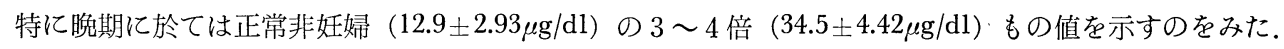
又, 正常分婏時母体血においては，さらに増量を初め，初産婦は $62.0 \pm 9.51 \mu \mathrm{g} / \mathrm{dl}$, 経産婦では $42.5 \pm$ $4.62 \mu \mathrm{g} / \mathrm{d} 1$ と副腎皮質機能に充分な予備能力のあるととを認めた。臍帯血はともに母体血值より低值を 示し, 胎般の何らかの功妙な作用によるものと思はれた。妊娠時血漿 17-OHCS の漸次増量する主な 原因を追求するために，去势婦人に Estradiol benzoate を投与した結果，3 日後には投与前值の約 4 倍の值を示し，妊娠時の Estrogen 増量の意義を裹付ける結果をえた。更に，妊婦に Estradiol benzoate を投与した場合も有意の差をもつて增量をみたが，去勢婦人に見られた程の增量は認められ なかつた。
\end{abstract}

\section{I 緒言}

生命維持に不可欠である腎副機能に関する研究は1829年 Addisonによつて行なはれ，それ以来，極めて 多数の基礎的，並びに臨床的研究がなされてきているが，今日未だ明かでないとてろも多数にみられる。

副腎皮質に対し，Selye ${ }^{1)}$ は Hypothalamic anterior pituitary adrenal cortical system の防衛機転を 展開させ，乙の形態を General adaptation syndrome と呼んだが，乙れ以来ての分野における業績は特に

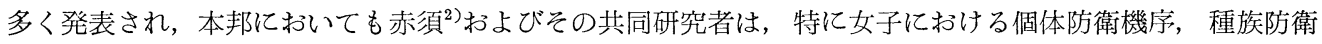
機序としての下垂体副婜皮質系について, 性差の概念を導入し各方面から検討し今日に至つている，さて， 周知の如く, 副腎皮質からはいろいろな Steroids が分泌されているが，大別すると Mineralocorticosteroids としての Aldosterone, Cortisol を主とする Glucocorticosteroids, 及び Androgen（いわゆる 17-ketosteroids の大部分), Estrogen などの Sexsteroids であるが, 所謂 Stress 時に密接な関連をもって変動する ものは Glucocorticosteroids であるために，ての系の直接的な Index として 流血中好酸球数の算定， ACTH 活性，血中及び尿中 17-hydroxycorticosteroids（以下 17-OHCS と略）值の測定，尿中 17ketosteroids（以下 17-KS と略）值の測定等がとりあげられ，中でも尿中及び血中の 17-OHCS 值の測定 が重要視され，最近では技術上の問題も含めて，11-OHCS などの測定も可なり広く行なわれる様になって いる. Corticosteroids（以下 $\mathrm{Cds}$ と略）は生体内外の環境変動に附随し，遂次変化して行くので，時間的 因子を追求する場合は尿中 17-OHCS 值測定では，その時点に於ける副腎皮質機能を知ることが出来ない ので, ての点から血中 Cds 濃度の測定が重要となり, 臨床的にも極めて意義が大きいというととができる. 人血漿中遊離型 17-OHCS 測定は1950年 Silber and Porter ${ }^{3}$ ) が 17-21-dihydroxy-10-ketosteroid 即ち, Comp. E,F,S, 及び，その Tetrahydro 型に極めて特異的に反応する Phenylhydrazine 反応を用いて定量 しているが，以後本法に基盤をおいた血中 17-OHCS 定量法として, Nelson and Samuels's) (1952), Bayliss 
and Steinbeck ${ }^{5)}$ (1953), Bliss et $\mathrm{al}^{6)}$. (1953), Silber and Busch ${ }^{7)}$ (1956), Migeon et $\mathrm{al}^{8)}$. (1956), Peterson et $\mathrm{al}^{9)}$. (1957) などがあり，それぞれ独自の方法で発表している.

妊娠時に副埥に変化がみられることは古くから多数の文献 ${ }^{10)-12)}$ の示すととろで，副腎皮質機能は充進し ているとされている，同時に胎盤からの $\mathrm{Gds}$ 分泌が問題となる，乙れは赤須 ${ }^{13)} ら の$ 妊娠動物から両側の副 腎を剔除したとき, 非妊動物の同様処置群に比して存命力がやや長いという点からも考えられるが, 弤娠時 の尿中ホルモン量の増加をもって推定している研究が多く,たとへば Venning ${ }^{14)}$ (1946) の Bioassay によ る Gds 值, Heard et $\mathrm{al}^{15)}$. (1946), Tobian ${ }^{16)}(1948)$, Devis et $\mathrm{al}^{17)}$. (1950), 沢崎 ${ }^{18)}$ (1953), 松下 ${ }^{19)}(1953)$, 加賀山 ${ }^{20)}$ (1954), 赤須 ${ }^{2}$ (1955), 小西 ${ }^{21)}$ (1955) などによる Chemocorticoids 值の報告がそれである. 又 血中関係では, Gemzell22) (1953), Assali et $\mathrm{al}^{23}$. (1955) らによれば, 晚期妊娠の血中 17-OHCS 值は正 常の 4 倍もの值を示したという。乙の様な大量の Cds は, 従来言はれている free 17-OHCS の中に一時 的に生物学的不活性の状態にある Cortisol binding globulin ${ }^{24)}$ (以下 GBG と略) を解離させた総值と考えら れる。乙れらの点を順次解明するため, まず第 1 歩として, 著者は Peterson et al. による従来の血中遊離 型 17-OHCS 測定法に若干の検討を加え，(1)正常婦人の性周期による変動，(2)去势婦人に Estradiol benzoate 投与の場合，(3)妊馬血清ゴナドトロピンあるいは閉経期婦人尿中ゴナドトロピン投与などによる変化， (4)更に弤婦, 産婦の血液, 臍带血, 弤娠時の ACTH response, 妊娠に対する Estradiol benzoate 投与例 などの場合の血漿中 17-OHCS 值を測定したのでその成績について記述する。

\section{II 実験材料及び実験方法}

\section{(A) 実験材料}

対象とした婦人は金沢大学医学部附属病院産科婦人科を受診した患者及び看護学校学生で，採血は日内変 動を考慮に入れ，原則として午前 6 時から午前 8 時の間に肘静脈から行ない，臍帯血は胎児婏出後湾帯搏動 停止直後に断端から採血を行なった．血液凝固阻止剤としては Heparin を加え，採血後，30分以内に遠心 分離し，測定に移した。なお，腎，朋などに機能障害のある患者及び溶血した症例は測定しなかった。

(B) 試 薬

1) Dichloromethane (市販特級試薬); 特級 $\mathrm{NaOH} 50 \mathrm{~g}$ に対し試薬 $1000 \mathrm{ml}$ の比で加え，50〜60 $\mathrm{C} 2$ 回減圧蒸溜し, 最初と最後の $100 \mathrm{ml}$ は捨て, 褐色瓶に入れ, 冷暗所に保存し, 1 ケ月以内に使用した.

2) Ethylalcohol (市販特級試薬)；2,4 dinitrophenylhydrazine $2.5 \mathrm{~g}$ に 1000ml Ethylalcohol 。を加え， $80^{\circ} \mathrm{C}$ で蒸溜精製を 2 回行ない，前後の $100 \mathrm{ml}$ は捨てた.

3) $\mathrm{NaOH}$ (市販特級試薬)；再溜水で $0.1 \mathrm{~N}$ とし，冷暗所に保存した.

4) dil. $\mathrm{H}_{2} \mathrm{SO}_{4}$ (市販特級試薬) : 再蒸溜水 $100 \mathrm{ml}$ に対し $\mathrm{H}_{2} \mathrm{SO}_{4} 180 \mathrm{~g}$ 加え64\%とした.

5) Phenylhydrazine sulfate ; 再溜水に Phenylhydrazinesulfate を加え, 溶解し，活性炭で脱色後， Ethylalcohol で再結晶を行なった，ての行程を 3 回行なう.

6) Blank reagent; $64 \% \mathrm{H}_{2} \mathrm{SO}_{4}$ と Ethylalcohol を2:1の比で混合し Blank reagent とした.

7) Phenylhydrazine sulfuric acid reagent; Blank reagent $10 \mathrm{ml} に 10 \mathrm{mg} の$ Phenylhydrazine sulfate を加え，測定毎に作製した。

(C) 測定法

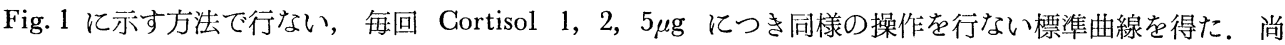
Microcuvettes は Light pass $10 \mathrm{~mm}$, Sample 量0.13mlを使用した.

1 ）吸収曲線 : Cortisol $5 \mu \mathrm{g}$ 及び血漿について，前述の抽出操作によって得たものに，波長 $400 \mathrm{~m} \mu$ よ り $450 \mathrm{~m} \mu$ の間で各波長毎にそれぞれの吸光度を測定し，Fig. 2 に示す吸収曲線を得た，再者とも $410 \mathrm{~m} \mu$ に最大吸収值を示した。

2 ) 標準曲線

既知量の Cortisol $1 \mu \mathrm{g}, 2 \mu \mathrm{g}, 5 \mu \mathrm{g}$ と再溜水を加え全量を $5 \mathrm{ml}$ とし 5 倍量の Dichloromethane にゆっく 
Fig. 1. Procedure for extration of 17-OHCS in plasma.

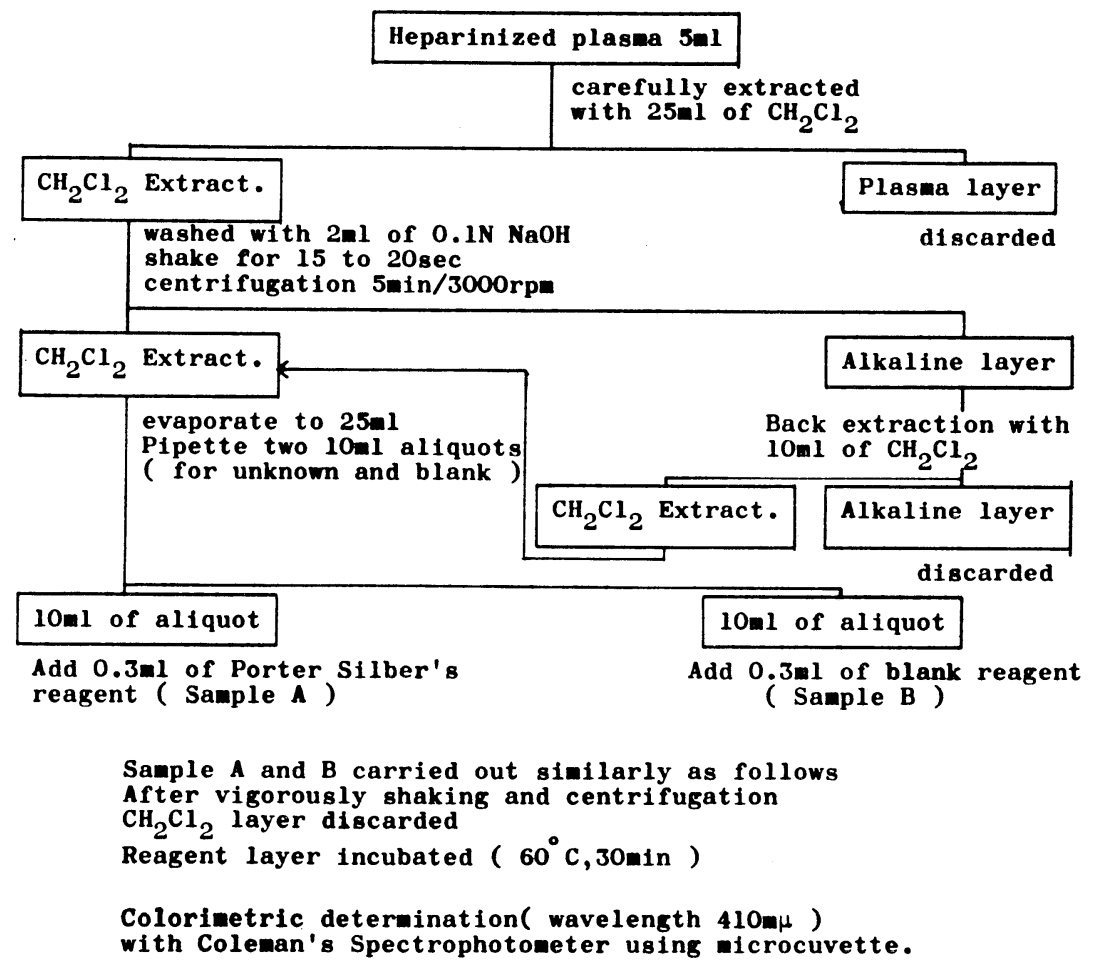

り, 静かれ加え, てれに前述のでとき抽出操作を行ない, 最大吸収波長 $410 \mathrm{n} \mu$ でそれぞれの吸光度を測定 した結果 Table 1 亿示す值を得た。これらを図に示すと Fig. 3 のでとくになり, 吸光係数(K) は 0.96〜0.83 で, 各群の四光係数には多少の変動はあるが, これは測定条件の差であり, 同一群, 各量における係数はよ く一致した。尚回収率は $94.2 \%$ でった。

3 ）日内変動

正常婦人につき，種々な時間に肘静脈より採血し，その 17-OHCS 值を測定した所 Fig. 4 亿示す結果を 得, 早朝時は概して高值を示し, 次第に娍少した。

\section{III 実 験 成 績}

(A) 本邦正常婦人の月経周期による血漿中 17-OHCS 值の変動

正常月経周期を有する18才から 22 才までの婦人 13 例につき，性周期第 7 日，14日および21日に区分し，そ の血漿 17-OHCS 值を測定した結果，月経周期第 7 日目の卵胞期では 9.4〜 13.5 $\mu \mathrm{g} / \mathrm{dl}$ で平均值が $11.5 \pm$ $1.69 \mu \mathrm{g} / \mathrm{dl}, 14$ 日目の排卵期では $14.3 \sim 17.7 \mu \mathrm{g} / \mathrm{dl}$, 平均 $16.2 \pm 1.24 \mu \mathrm{g} / \mathrm{dl}, 21$ 日目の黄体期では $8.8 \sim 12.4 \mu \mathrm{g} / \mathrm{dl}$, 平均 $10.5 \pm 1.50 \mu \mathrm{g} / \mathrm{dl}$ で, 排卵期が最も高く，ついで卵胞期，黄体期の順であった，尚これら全ての平均值 は $12.9 \pm 2.93 \mu \mathrm{g} / \mathrm{dl}$ で，乙れを正常非妊婦の正常值とし対照值とした (Table 2). ての様な変動はEstrogen や Gonadotropin などの性器外作用によるものと思はれ，乙の事実を証明するものとして，去勢婦人に Estradiol benzoate (以下 Ed. benz. と略) $2 \mathrm{mg}$, あるいは妊馬血清 Gonadotropin (以下 PMS-G と略) 総量で4000 6000単位，又は，閉経婦人尿中 Gonadotropin（以下 HMG と略）1日 150iu．投与した症 例につき血中 17-OHCS 值を測定した結果 Ed. benz. 投与群 5 例，全てに增加傾向を示し特に投与後 3 日 目に著名な増量を見た (Table 3). 又 PMS-G 2000i.u., 3000i.u., を 2 日間に渡り投与し，投与後 2 日，3 日 
Fig. 2. Average optical dencity at vatious wavelength of Porter Silber chromogen (Sample A-Sample B.)

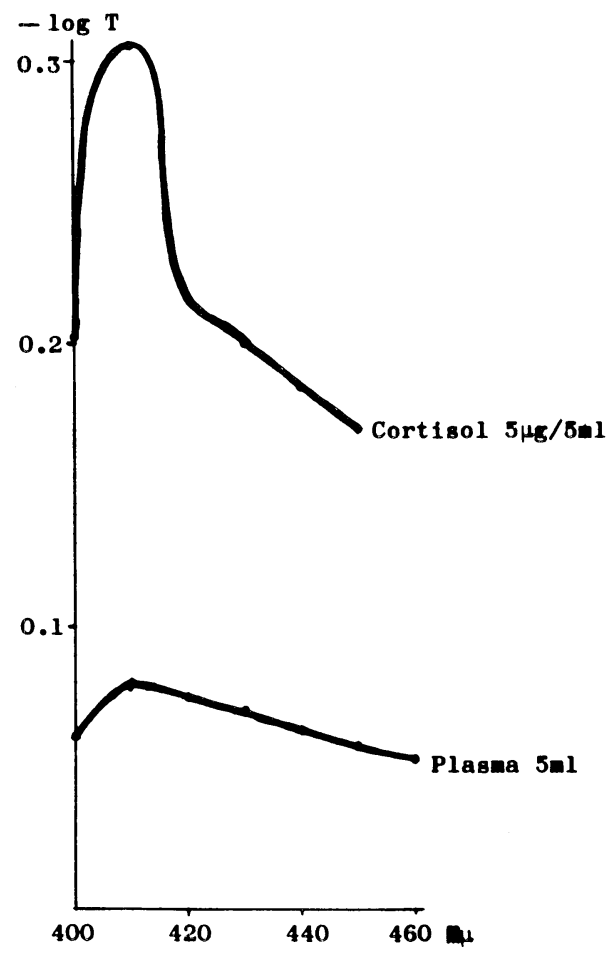

Table 1. Sample experiment

\begin{tabular}{l|c|c|c|c|c}
\hline \multirow{2}{*}{ Sample } & \multicolumn{2}{|c|}{ Optical density of } & A-B & $\begin{array}{c}\text { COD } \\
\text { A-B }-\mathrm{Bl})\end{array}$ & $\mathrm{K}$ \\
\cline { 2 - 3 } & Sample (A) & Blank (B) & & & \\
\hline \hline Blank $\left(\mathrm{H}_{2} \mathrm{O} 5 \mathrm{ml}\right)$ & 0.027 & 0.003 & 0.024 & & \\
$1 \mu \mathrm{g}+\mathrm{H}_{2} \mathrm{O} 4 \mathrm{ml}$ & 0.080 & 0.003 & 0.077 & 0.053 & 0.94 \\
$2 \mu \mathrm{g}+\mathrm{H}_{2} \mathrm{O} 3 \mathrm{ml}$ & 0.139 & 0.009 & 0.130 & 0.106 & 0.94 \\
$5 \mu \mathrm{g}$ & 0.300 & 0.010 & 0.290 & 0.266 & 0.94 \\
\hline $\mathrm{Blank}\left(\mathrm{H}_{2} \mathrm{O} 5 \mathrm{ml}\right)$ & 0.041 & 0.004 & 0.037 & & \\
$1 \mu \mathrm{g}+\mathrm{H}_{2} \mathrm{O} 4 \mathrm{ml}$ & 0.093 & 0.004 & 0.089 & 0.052 & 0.96 \\
$2 \mu \mathrm{g}+\mathrm{H}_{2} \mathrm{O} 3 \mathrm{ml}$ & 0.146 & 0.006 & 0.140 & 0.103 & 0.97 \\
$5 \mu \mathrm{g}$ & 0.305 & 0.010 & 0.295 & 0.258 & 0.97 \\
\hline $\mathrm{Blank}\left(\mathrm{H}_{2} \mathrm{O} 5 \mathrm{ml}\right)$ & 0.035 & 0.010 & 0.025 & & \\
$1 \mu \mathrm{g}+\mathrm{H}_{2} \mathrm{O} 4 \mathrm{ml}$ & 0.095 & 0.010 & 0.085 & 0.060 & 0.83 \\
$2 \mu \mathrm{g}+\mathrm{H}_{2} \mathrm{O} 3 \mathrm{ml}$ & 0.155 & 0.010 & 0.145 & 0.120 & 0.83 \\
$5 \mu \mathrm{g}$ & 0.341 & 0.014 & 0.327 & 0.302 & 0.83 \\
\hline
\end{tabular}


Fig. 3. Standard curve for extraction from standard solution

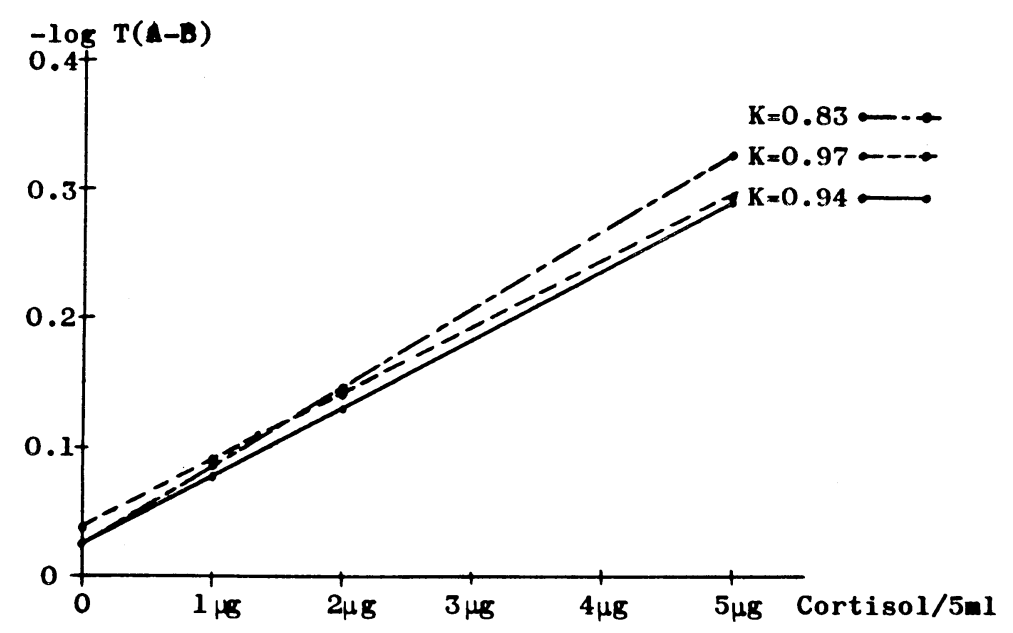

Fig. 4. Diurnal variations of plasma 17-OHCS levels at various times

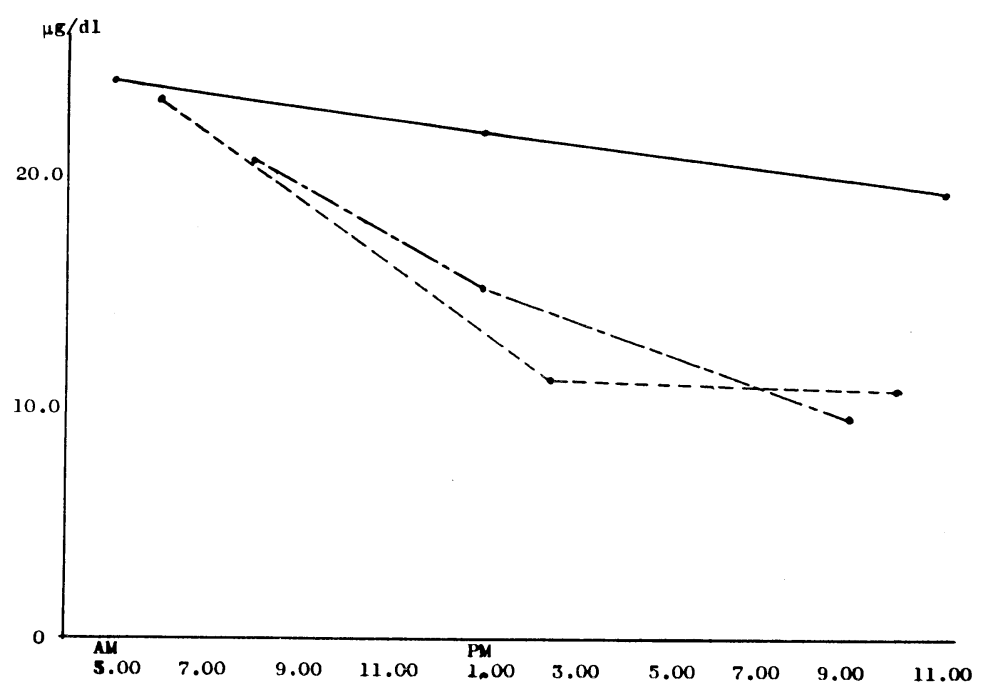

および 4 日について 17-OHCS 值を測定した結果, 軽度であるが上昇傾向を示し, 投与後 2 日目に Peakを 示すものが多く 3 日〜 4 日には減少傾向を示した，もっともとれら PMS-G は異種蛋白としての作用が考 えられるために非去势婦人であるが，PMS-G 療法無効の患者の例につきHMG を投与したとてろ第 3 日 目の血中 17-OHCS 值は投与前值の 2 倍量以上の高值を示した (Table 4).

(B) 正常妊娠に於ける血漿中 17-OHCS の変動

正常妊婦の, 妊娠 2 ケ月より10ケ月までの37例につき，妊娠月数の進行に伴なう血漿 17-OHCS 值の変動 を観察した．37例中経産婦17例，初産婦20例で年令分布は21才から32才であった。血中 17-OHCS 值は妊 娠 2 ケ月及び 3 ケ月は, 正常非妊婦と大差がなかったが, 以後, 月数の進むにつれ漸次上昇し, 中期では正 常非妊婦の 2 倍，10ケ月では平均 $34.5 \pm 4.42 \mu \mathrm{g} / \mathrm{d} 1$ で非妊時の 3 倍もの值に上昇した（Table 5, Fig. 5)。 
Table 2. Plasma 17-OHCS levels in menstrual cycle $(\mu \mathrm{g} / \mathrm{dl})$

\begin{tabular}{l|c|c|r|c}
\hline Name & Age & Menstrual cycle & 17-OHCS level & Mean value \\
\hline \hline E.T. & 18 & & 11.2 & \\
T.T. & 19 & 7th. day & 9.4 & $11.3 \pm 1.69$ \\
H.K. & 18 & & 11.2 & \\
T.E. & 19 & & 13.5 & \\
\hline S.K. & 20 & & 16.5 & \\
H.M. & 19 & & 15.9 & \\
W.M. & 18 & 14th. day & 14.3 & $16.2 \pm 1.24$ \\
T.T. & 19 & & 16.5 & \\
K. I. & 19 & & 17.7 & \\
\hline M.H. & 18 & & 10.0 & \\
O.M. & 22 & 21th. day & 12.4 & \multirow{2}{*}{$10.5 \pm 1.50$} \\
O.T. & 19 & & 8.8 & \\
Y.T. & 19 & & 10.6 & \\
\hline
\end{tabular}

Total mean value $12.9 \pm 2.93 \mu \mathrm{g} / \mathrm{dl}$

Table 3. Plasma 17-OHCS levels of castrated females following administration of estradiolbenzoate in a single dose of $2 \mathrm{mg}$

\begin{tabular}{|c|c|c|c|c|c|}
\hline No. & Name & Age & $\begin{array}{l}\text { Diagnosis } \\
\text { Operation }\end{array}$ & $\begin{array}{l}\text { Pretreated } \\
\mu \mathrm{g} / \mathrm{dl}\end{array}$ & $\begin{array}{l}3 \text { days after administration of } \\
\text { estradiolbenzoate }(\mu \mathrm{g} / \mathrm{dl})\end{array}$ \\
\hline 1 & S.A. & 57 & $\begin{array}{l}\text { Carc. in situ } \\
\text { Panhysterect. }\end{array}$ & 12.5 & 15.0 (2 days) \\
\hline 2 & M.S. & 62 & $\begin{array}{l}\text { Carc. st. III } \\
\text { Panhysterect. }\end{array}$ & 9.2 & 14.2 (2 days) \\
\hline 3 & H.S. & 58 & $\begin{array}{l}\text { Garc. st. I } \\
\text { Panhysterect. } \\
\text { Radiations th. }\end{array}$ & 13.5 & 15.8 (2 days) \\
\hline 4 & K.Y. & 48 & $\begin{array}{l}\text { Carc. in situ } \\
\text { Total hyst. }\end{array}$ & 8.3 & 36.7 \\
\hline 5 & $\mathrm{Y} . \mathrm{Y}$ & 37 & $\begin{array}{l}\text { Carc. st. I } \\
\text { Panhysterect. }\end{array}$ & 7.9 & 40.8 \\
\hline
\end{tabular}

Table 4. Plasma 17-OHCS levels of castrated females following adnimistration of PMS-G in dose of 4000 i.u. and 6000 i.u. (2000 or 3000 i.u./day)

\begin{tabular}{l|c|c|c|c|c|c|c|c}
\hline $\begin{array}{l}\text { Case } \\
\text { No. }\end{array}$ & Name & Age & Diagn. & $\begin{array}{c}\text { Dose of } \\
\text { PMS-G }\end{array}$ & \multicolumn{2}{|c|}{ Plasma } & 17-OHCS level $(\mu \mathrm{g} / \mathrm{dl})$ \\
\hline \hline 1 & T.Y. & 24 & Carcinoma in situ & 4000 & 13.1 & $\begin{array}{l}\text { afler } \\
\text { 2days }\end{array}$ & $\begin{array}{l}\text { after } \\
\text { 3days }\end{array}$ & $\begin{array}{l}\text { after } \\
\text { 4days }\end{array}$ \\
2 & T. A. & 56 & Normal & 4000 & 11.5 & 12.7 & & 15.5 \\
3 & M.T. & 28 & Dermoidcyste & 6000 & 28.9 & 31.8 & & 22.1 \\
4 & S.N. & 24 & Ectopic preg. & 6000 & 13.8 & 26.3 & 25.4 & \\
5 & S.W. & 30 & Carcinoma in situ & 6000 & 27.8 & 30.4 & 19.2 & \\
$6 *$ & K.S. & 26 & Hypofnnctio ovarii & HMG & 12.4 & & 27.1 & \\
\hline \hline
\end{tabular}


Table 5. Plasma 17-OHCS levels in normal pregnancies

\begin{tabular}{|c|c|c|c|c|c|}
\hline Name & Age & Para & Months of preg. & $17-\mathrm{OHCS}(\mu \mathrm{g} / \mathrm{dl})$ & Average of $17-$ OHCS $(\mu \mathrm{g} / \mathrm{dl})$ \\
\hline $\mathrm{Y} . \mathrm{F}$. & 32 & 1 & II & 12.6 & \multirow{2}{*}{$14.9 \pm 2.30$} \\
\hline $\mathrm{K} \cdot \mathrm{T} \cdot$ & 27 & 1 & II & 17.2 & \\
\hline I. I . & 29 & 2 & III & 19.2 & \multirow{3}{*}{$14.1 \pm 3.81$} \\
\hline A.S. & 25 & 1 & III & 13.0 & \\
\hline N.S. & 30 & 2 & III & 10.0 & \\
\hline M. Y . & 23 & 1 & $\mathrm{VI}$ & 23.0 & \multirow{4}{*}{$17.0 \pm 4.35$} \\
\hline E.S. & 27 & 0 & VI & 11.3 & \\
\hline K. S. & 23 & 0 & $\mathrm{VI}$ & 15.0 & \\
\hline M.K. & 27 & 0 & $\mathrm{VI}$ & 18.8 & \\
\hline N.S. & 26 & 0 & $\mathrm{~V}$ & 22.4 & \multirow{5}{*}{$23.0 \pm 4.34$} \\
\hline H.K. & 30 & 0 & $\mathrm{~V}$ & 19.6 & \\
\hline $\mathrm{K} \cdot \mathrm{N}$. & 31 & 0 & $\mathrm{~V}$ & 23.8 & \\
\hline S.H. & 29 & 0 & $\mathrm{~V}$ & 30.0 & \\
\hline $\mathrm{F} \cdot \mathrm{K}$. & 28 & 0 & $\mathrm{~V}$ & 19.3 & \\
\hline $\mathrm{K} \cdot \mathrm{K}$ & 29 & 1 & $\mathrm{VI}$ & 23.3 & \multirow{5}{*}{$26.8 \pm 6.24$} \\
\hline S. I . & 22 & 0 & $\mathrm{VI}$ & 37.8 & \\
\hline $\mathrm{Y} \cdot \mathrm{N}$. & 24 & 0 & $\mathrm{VI}$ & 23.0 & \\
\hline $\mathrm{F} \cdot \mathrm{U}$ & 29 & 1 & $\mathrm{VI}$ & 22.8 & \\
\hline N.H. & 24 & 0 & VI & 27.0 & \\
\hline $\mathrm{Y} . \mathrm{T}$. & 22 & 0 & VII & 22.6 & \multirow{4}{*}{$26.7 \pm 2.99$} \\
\hline N.K. & 30 & 1 & VII & 29.5 & \\
\hline M.M. & 24 & 1 & VII & 26.3 & \\
\hline $\mathrm{Y} . \mathrm{F}$. & 29 & 0 & VII & 28.4 & \\
\hline $\mathrm{Y} . \mathrm{K}$. & 29 & 1 & VIII & 34.0 & \multirow{4}{*}{$27.9 \pm 6.84$} \\
\hline Y.S. & 28 & 1 & VIII & 31.8 & \\
\hline H. T. & 31 & 0 & VIII & 18.4 & \\
\hline $\mathrm{Y} . \mathrm{N}$. & 22 & 1 & VIII & 27.2 & \\
\hline $\mathrm{T} . \mathrm{S}$ & 30 & 1 & IX & 28.4 & \multirow{5}{*}{$32.0 \pm 4.52$} \\
\hline E.O. & 29 & 0 & IX & 39.8 & \\
\hline E.H. & 23 & 0 & IX & 31.2 & \\
\hline K.Y. & 21 & 0 & IX & 30.8 & \\
\hline M.M. & 32 & 3 & IX & 29.6 & \\
\hline $\mathrm{F} \cdot \mathrm{M}$ & 22 & 0 & $\mathrm{X}$ & 33.3 & \multirow{5}{*}{$34.5 \pm 4.42$} \\
\hline $\mathrm{Y} \cdot \mathrm{F}$. & 22 & 0 & $\mathrm{X}$ & 29.7 & \\
\hline A.N. & 22 & 0 & $\mathrm{X}$ & 32.6 & \\
\hline M. S. & 30 & 1 & $\mathrm{X}$ & 40.5 & \\
\hline N.M. & 29 & 1 & $\mathrm{X}$ & 36.5 & \\
\hline
\end{tabular}


Fig. 5. Plasma 17-OHCS levels in normal pregnancies.

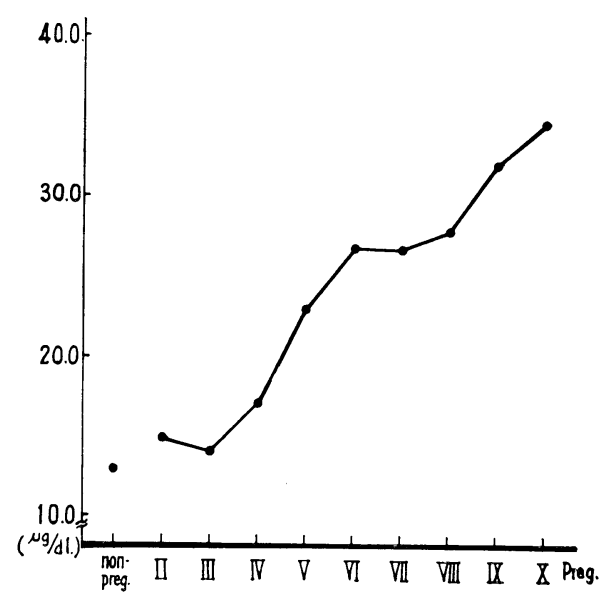

(C) 晚期正常妊婦の ACTH 及び Ed. benz. 投与による変動.

正常弤娠第 9 ケ月 2 例, 第10ケ月13例の計15例, 年令 21 2 29 才G AH 25単位を筋注投与し, 投与後 30 分, 1 時間, 2 時間 および 3 時間の血中 17-OHCS 值を測定した. 投与後 30 分 は 7 例で平均増加率 24.2 $\%, 1$ 時間後は 3 例で $35.8 \% ， 2$ 時間後 $82.3 \% ， 3$ 時間後は $121.2 \%$ で，内 1 例に於いて，分婏第 1 期に 対照值を取り，3 時間後は分婏第而期であったため異常な高值を示したものと思われ，本症例を除外すると

Table 6. Plasma 17-OHCS levels following administration of ACTH 25 I.U. to normal pregnant women

\begin{tabular}{|c|c|c|c|c|c|}
\hline \multirow{2}{*}{ Name } & \multirow{2}{*}{ Age } & \multirow{2}{*}{$\begin{array}{l}\text { Month. } \\
\text { of } \\
\text { pregn. }\end{array}$} & \multirow{2}{*}{$\begin{array}{l}\text { Hours after } \\
\text { administration } \\
\text { of ACTH }\end{array}$} & \multicolumn{2}{|c|}{ Plasma 17-OHCS level $(\mu \mathrm{g} / \mathrm{d} l)$} \\
\hline & & & & Before ACTH & After ACTH \\
\hline A.Y. & 21 & IX & $30^{\prime}$ & 29.3 & 35.5 \\
\hline M. E. & 24 & $\mathrm{X}$ & $30^{\prime}$ & 32.3 & 44.1 \\
\hline Y.Y. & 25 & $\mathrm{X}$ & $30^{\prime}$ & 28.3 & 31.7 \\
\hline M. S . & 27 & $\mathrm{X}$ & $30^{\prime}$ & 30.1 & 38.6 \\
\hline H. T. & 25 & $\mathrm{X}$ & $30^{\prime}$ & 33.1 & 35.9 \\
\hline A.O. & 28 & $\mathrm{X}$ & 1 & 31.5 & 42.7 \\
\hline $\mathrm{K} . \mathrm{K}$. & 25 & $\mathrm{X}$ & 1 & 28.8 & 44.8 \\
\hline M. G. & 22 & IX & 1 & 34.5 & 41.3 \\
\hline M.N. & 23 & $\mathrm{X}$ & 2 & 34.4 & 64.8 \\
\hline \multirow[t]{2}{*}{ T. I . } & 21 & $\mathrm{X}$ & $30^{\prime}$ & 26.7 & 33.9 \\
\hline & & & 2 & & 43.2 \\
\hline \multirow[t]{2}{*}{$\mathrm{K} . \mathrm{U}$} & 26 & $\mathrm{X}$ & $30^{\prime}$ & 28.0 & 35.2 \\
\hline & & & 2 & & 54.4 \\
\hline H.M. & 23 & $\mathrm{X}$ & 3 & 22.7 & 60.8 \\
\hline N.N. & 27 & $\mathrm{X}$ & 3 & 26.7 & 79.2 \\
\hline Y.M. & 26 & $\mathrm{X}$ & 3 & 60.6 & $137.5^{*}$ \\
\hline Y.S. & 29 & $\mathrm{X}$ & 3 & 31.7 & 80.0 \\
\hline
\end{tabular}

*Baby born one hour after administration of ACTH 
Fig. 6. Changes of plasma 17-OHCS levels following administration of ACTH 25I.U. to normal pregnant worren.
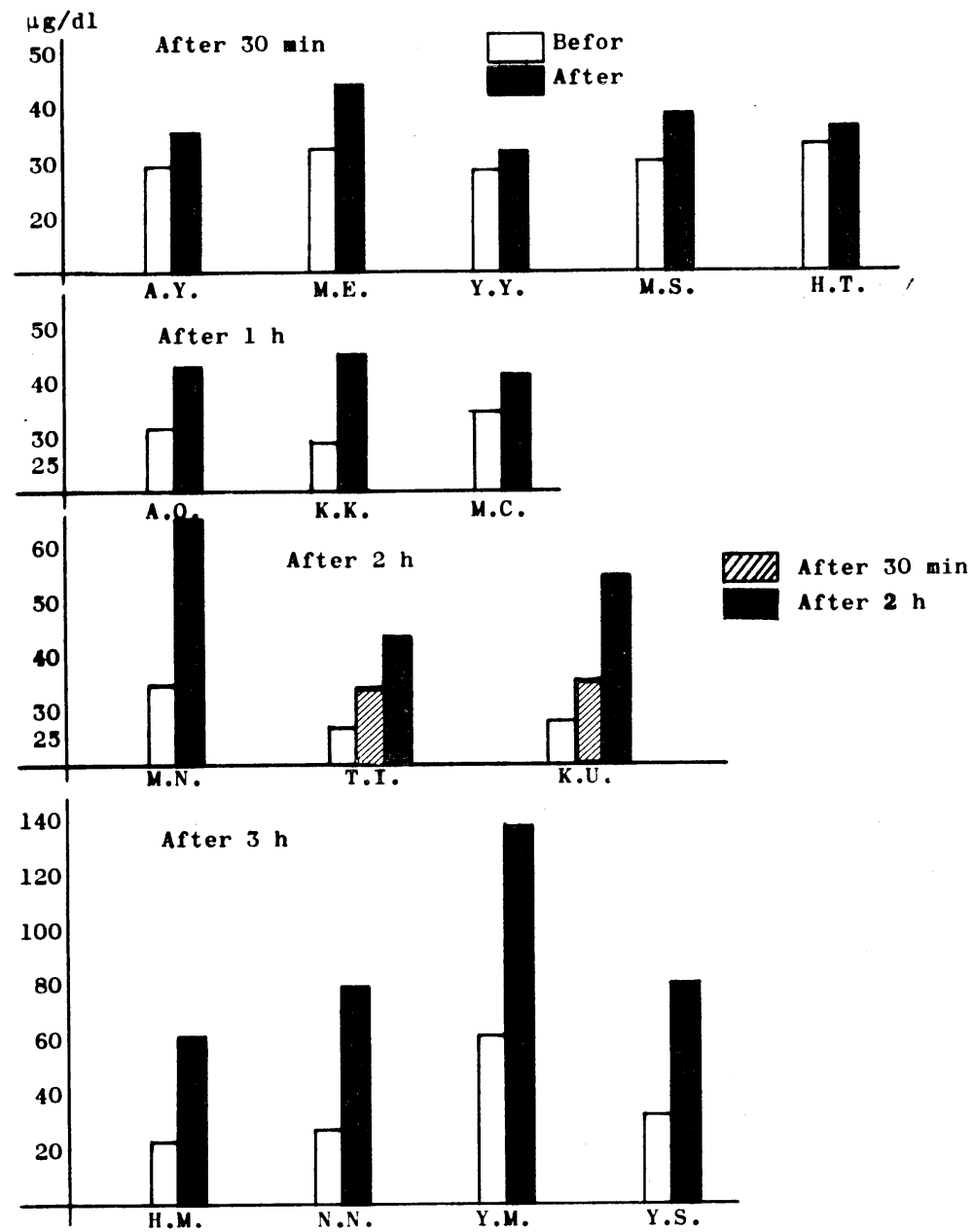

平均増加率 $171.3 \%$ であった。 (Table 6, Fig. 6).

晚期正常妊婦に Ed. benz. の投与を行なった場合，正常非妊婦で max. であった投与後 3 日に於いて は平均 $9.9 \mu \mathrm{g} / \mathrm{dl}$ の上昇で増加率は $29.8 \%$ を示し，正常非妊婦の増加率をやや下まわる結果となった (Table 7).

(D) 正常分婏時の母体血及び臍帯血の 17-OHCS 值の変動

正常妊娠分婏時の初产婦 7 名, 年令 20 才〜 27 才, 経産婦 6 名, 年令 25 才〜 28 才につき, 分婏第而期に时静 脈より採血し，臍帯血は臍帯拍動停止直後，断端より採血を行なった。

初産婦の血中 17-OHCS 值の平均值は $62.0 \pm 9.51 \mu \mathrm{g} / \mathrm{dl}$, 臍帯血は $24.0 \pm 4.16 \mu \mathrm{g} / \mathrm{dl}$, 母体血と臍帯血の比

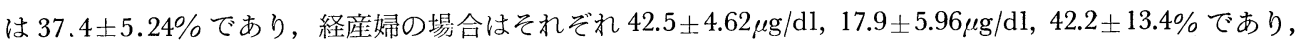
初産婦に於いては母体血值及び臍带血值は何れも経産婦のそれらより高值を示した，ただ母体血值と臍帯血 值の比率は両者の間に差異はない様に思われる (Table 8). 
Table 7. Changes of plasma 17-OHCS levels of normal pregnant women following administration of estradiolbenzoate in a single dose of $5 \mathrm{mg}$

\begin{tabular}{l|c|c|c|c|c|c}
\hline \hline Name & Age & Para & Month. of pregn. & \multicolumn{2}{|c|}{$\begin{array}{c}\text { Plasma 17-OHCS }(\mu \mathrm{g} / \mathrm{d} l) \\
\text { After/Befor } \\
(\%)\end{array}$} \\
\hline \hline M.O. & 23 & 0 & IX & 38.1 & 47.7 & 155.5 \\
I.Y. & 21 & 0 & IX & 22.3 & 29.1 & 130.5 \\
S.T. & 25 & 1 & IX Twins & 29.4 & 33.2 & 112.9 \\
M.K. & 20 & 0 & X & 34.3 & 52.9 & 154.2 \\
A.S. & 26 & 1 & X & 40.6 & 55.4 & 136.5 \\
M.Y. & 27 & 1 & IX & 27.4 & 40.5 & 149.8 \\
G.M. & 26 & 0 & X & 23.7 & 35.3 & 148.9 \\
S.O. & 29 & 1 & X & 26.9 & 41.9 & 155.8 \\
S.U. & 35 & 2 & X & 29.4 & 37.0 & 125.9 \\
S.N. & 29 & 0 & X & 31.6 & 40.4 & 127.8 \\
\hline & & & & $30.4 \pm 5.9$ & $41.4 \pm 8.5$ & $139.6 \pm 14.9$ \\
\hline
\end{tabular}

Table 8. Levels of 17-OHCS in maternal and cord plasma in normal deliveries $(\mu \mathrm{g} / \mathrm{dl})$

\begin{tabular}{c|c|c|c|c|c}
\hline Name & Age & Para & Maternal. & Cord. & Cord/mater. (\%) \\
\hline M.O. & 20 & 0 & 65.8 & 24.9 & 36.3 \\
S.K. & 25 & 0 & 71.2 & 25.6 & 34.5 \\
F.K. & 21 & 0 & 69.2 & 24.9 & 34.5 \\
S.N. & 23 & 0 & 66.9 & 22.2 & 31.7 \\
M.K. & 26 & 0 & 43.6 & 18.5 & 40.2 \\
Y.T. & 27 & 0 & 59.6 & 29.4 & 47.7 \\
K.Y. & 23 & 0 & 57.6 & 22.1 & 36.7 \\
M.T. & 28 & 2 & 36.2 & 12.7 & 35.1 \\
T.M. & 26 & 1 & 49.6 & 13.8 & 27.8 \\
S.H. & 28 & 1 & 40.4 & 15.0 & 37.1 \\
K.U. & 25 & 1 & 52.4 & 25.2 & 48.1 \\
M.H. & 26 & 1 & 39.0 & 25.8 & 66.1 \\
K.K. & 28 & 1 & 37.4 & 14.7 & 39.3 \\
\hline Mean & primipara & $62.0 \pm 9.51$ & $24.0 \pm 4.16$ & $37.4 \pm 5.24$ \\
value & \multicolumn{2}{|l}{ multipara } & $42.5 \pm 4.62$ & $17.9 \pm 5.96$ & $42.2 \pm 13.4$ \\
\hline
\end{tabular}

\section{IV 考按}

(A) 血中 17-OHCS 測定についてまず述る.

冒頭にも述べたが, Homeostesis, Hypothalamic-anteroir pituitary-adrenal cortical system 等の生体 防衛機序の中核をなす Hormone として副腎皮質ホルモンが close up されて以来，乙の系の直接的な活 性度の指標として 17-OHCS の測定が用いられている。これは，1950年 Silber and Porter ${ }^{3)}$ にり Phenylhydrazine の 17, 21-dihydroxy-20-ketosteroid による呈色反応がその本態をなすもので，乙の原理は Gds. 分子中の Dihydroxyacetone 側鎖と Phenylhydrazine とにより Phenylhydrazone が形成され, 黄 
色の呈色反応を示すととによる．本法は，抽出エキスに直接試薬を反応させるため，Blankが高值を示すと とが欠点とされているとと, 又, 血中のものは尿中のものに比較し極めて微量であるととを思考し, 実験に 当っては試薬の精製に最も努力を払わなければならない. 又, 陚料が血獎であるために Sampling は出来 るだけ少量のことが必要であるために血中 17-OHCS 值の測定はいきおい微量定量に集約され，Nelson and Samuels $s^{4}$ ，Eik-Nes ${ }^{25)}$ ，Van der Vies ${ }^{26)}$ 等は極く微量で測定可能な方法を報告している。次いで routine 化するために簡便であるてとが要求され，Silber and Porter 法を改良した Peterson et a $1^{9)}$. 法が示された が，乙れは回収率も高く，臨床的にも立分応用出来るものと思われ，著者も多少てれを改良し実施したが， 陚料が溶血している場合や黄誼のある場合は Blank 值が著しく高值を示し, 吸光曲線も乱れ, 測定不能で あった，著者の用いた測定法は，回収率も高く，败光係数も各群で良く一致し，正常平均值に於いて Silber and Busch ${ }^{7}$, Wallace et $\mathrm{al}^{28)}$., Migeon et $\mathrm{al}^{8)}$., 渡辺・熊谷 ${ }^{28)}$, 井林 ${ }^{2} \zeta^{9)}$, 佐々木 $\zeta^{30)}$, 鈴木 ${ }^{31)}$, Watanabe ${ }^{32)}$ らの報告と略々一致し，臨床目的に充分適したものと思われる。

(B) 正常值及び性周期に伴なう変動について

血漿 17-OHCS の正常值について多くの報告があるが，測定法や採血時間の差異により当然ある程度の 変動はま妨れ得ない，それ故，私は外界からの Stress 等を考み，同一環境にある正常月経周期を有する 婦人を対象とし，採血時間は午前 6 時から午前 8 時までとし，性周期に伴なう変動もあわせて測定した。

日内変動についての報告はあるが，早朝時に Peak があり次第に低下するのが全て一致した報告であり ${ }^{6)}$

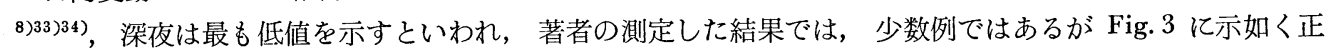
常婦人で早朝時が最も高く, 時間と伴に低下し, 深夜近くでは早朝時の $1 / 2$ の数值を示した.

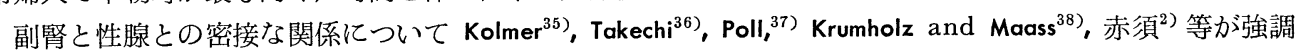
しているが，月経周期に関しての血漿 17-OHCS の報告は少ない，人については Pepper and Lindsay ${ }^{39)}$ (1960) の報告がある. 即ち12例の性周期に関する測定では，8例が排卵の前後48〜 72時間に 17-OHCS の Peak を認めている，著者の成績では全例を通じ排卵期が最も高く，次に卵胞期，黄体期の順であり，てれ らの変動は Estsogen の性器外作用, ととに対副腎作用がまず考えられ，加えて Gonadotropin の関与も 推定される。乙れに関連して著者は去勢婦人に Ed. benz. 及び PMS-G 投与の血中 17-OHCS 值測定を行 ない, Ed. benz. 投与群に於ては投与後 3 日目に投与前の $4 \sim 5$ 倍にも達した症例があった。副腎と Estr-

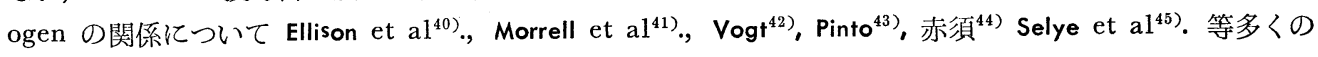
研究者によって Estrogen 投与が副腎重量の増加を来たすと報告されている，一方その変化が見られないと するもの ${ }^{\left.46^{4} 47\right)}$, 却って減少するとの報告 ${ }^{48}$ もあるが機能六進を報告するものが多く ${ }^{49)-51)}$, 教室名越 ${ }^{52}$ はEd. のみならず Estriol も尿中 17-OHCS 排泄值の上昇があると述べている，ただ Estrone 亿関しては投与に よる有意の差はないといわれている.

PMS-G に関しては異種蛋白としての Stress も考光られるために, 卵巣機能不全の症例に HMG を投与 したもの 1 例, PMS-G 投与群 5 例について検討した結果は個体差はあるが投与後 2 日目に多小の増加を認 め $3 \sim 4$ 日目には減少傾向を示すものがある一方，4 日目にして投与前の 3 倍を示すものがあった．Gona-

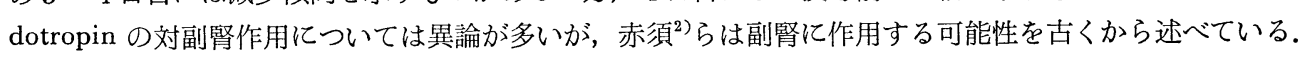
HMG 投与例は先に PMS-G 投与無効例について HMG を1日150単位連続10日間筋注行なったものにつ き投与前と投与後 3 日目の血墏 17-OHCS の測定を行なった所, 投与後 3 日目には投与前の 2 倍量もの高 值を示したもので, 直接 Gonadotropin が副腎え作用した事が強く推定される。なお Gonadotropin と副 腎との関係の業績は可なりあるが, こてでは省略する.

(C) 正常妊娠時血中 17-OHCS について

妊娠によって副腎に変化の起てる事は冒頭でも述べたが，赤須 ${ }^{2}$ は妊娠副腎の肥大はあるが体重に対する 副腎重量は静止期も妊娠前期及び後期共に全く差異のないととを指摘している。つまり重量だけを問題には できないというわけである. 又 Whiteley and Stoner ${ }^{53)}$, Delamare ${ }^{54)}$ は分婏後数日で肺結核で死亡した 3 例の 婦人に副腎肥大を認めており，乙れらの副腎肥大が胎盤性 Gds とするもの ${ }^{55)}$ ，副腎の機能六進とするもの 


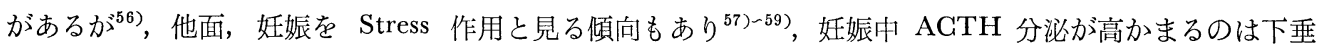
体以外の ACTH 源のあるととが推定され (赤須他 ${ }^{2}$ ), Corticotropin releasing factor の問題 Cds の Feed back, 分泌，排泄等が関与しているとも考えられ，胎盤の関連性がとり上げられているが，すべては 今後にあるといはねばならない．

赤須 ${ }^{13760}$ '61)の妊娠ラット副腎の組織学的研究では, 妊娠前期に Lipids は少く, 微細顆粒状を呈し, 後期 に於いて Lipids は多量で粗大顆粒状を呈しているのか見られ，Cholesterol 量は月数の進むにつれ漸次減 少するが，血清中の量はその反対の傾向を示し，Steroids hormones の材料源として動員されているものと

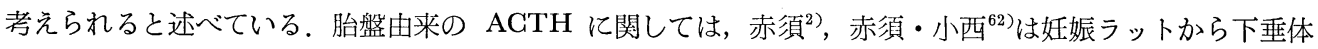
を剔除した時，胎児の発育を認めたが，乙れは胎盤からの Cds の産生を肯定するものである他，副腎重量 は減少しているが，組織的には菱縮を示さず，束状層の出血さえ見られるのは，AGTH（胎盤由来か？） により賦活されていたものと考えられ，妊娠ラットから両側副腎を剔除したとき，非妊動物に比し存命力が やや長いという点から胎盤 Cds の存在は推定されるが, 又, 一方尿中 Chemocorticoids が著減している ことは，副腎が妊娠後期でも可なり活動しているととを認めるものであり，下垂体剔除例はての減少がはる かに軽度である事は，下垂体が機能を著しく低下させているものと考えられると述べている。

正常妊娠の各月による血漿中 17-OHCS 值についての諸家の報告 ${ }^{22233) 63644}$ は一様に上昇しているととを認 め, 上昇程度に多少の相異はあるが, 私の成績では妊娠晩期に於いて非妊時の 2〜3 倍であり，17-OHCS の上 昇原因は今までに述べたでとく, 副腎皮質, 胎盤産生の Gds, 及び ACTH 様物質, Estrogen 産生の増加 等が主なものと考えられる．又胎児副腎からの Cds 分泌が母体えの移動は胎児及び生後 2 日で死亡した新 生児の副腎切片より Progesterone-4- ${ }^{14} \mathrm{C}$ 結合を証明出来なかったという報告 ${ }^{65}$ もりり，除外しても良いの ではないかと思う. 尚 Migeon et $\mathrm{al}^{66)}$ そよれば radioactive の Cortisol を妊婦に投与し，その後48時間 の尿中排泄を見ると，正常人に比べ遅延し，ての事から妊娠時の血中 Cds の増量原因の一つとして，代謝 の遅延が考えられ，血管内から体組織えの Cortisol の拡散が遅いために target organ の高値が現はれず Hypercorticoidism が見られないのだろうとしている。確に弤娠時に Cushing 症候群はみられない.けれ ぞも妊娠と Cushing 症候群とを比較すれば N-Balance に於いて相違があるのみで, 全体的に妊娠時は概 して Cushing 状態に近似した点もあるのを赤須は强調している. 又赤須 (7)によれば Cds の大量投与, あ るいは過剩分泌はたしかに catabolic な変動を生体に惹起させるけれども，適量の Gds はむしろ anabolic の作用をもち，妊娠はての状能にあるものであろうという。

現段階に於ける大勢としては，妊娠時従来から測定されている Free 17-OHCS 中には GBG 結合型も含 まれ，てれを除いた所滑 Protein free 17-OHCS 值は非妊時と大差なく, 妊娠時 Estrogen の著増などによ って, これらの Protein, 即ち Transcortin ${ }^{24) 68}$ が増加し, 種々な原因で増量した Cds は Transcortin と 結合し, 生物学的に略々不活性の状態にあると思われる $\mathrm{CBG}$ 結合型として存在するのではないかと思われ る. 著者 ${ }^{69}$ の CBG を除いた Free 17-OHCS のみの測定法では Free は弤娠晚期で 27.6\%, 非妊時は 60.6\%であった，尚 CBG に関しては著者は目下追究中である.

(D) 晚期正常妊娠時の ACTH response 及び Ed. 投与について

著者は ACTH 25単位筋注法を採用し，他の方法に上るものと大差ないととを認めた，即ち晚期正常妊 娠の AGTH response を投与後30分, 1 時間, 2 時間及び 3 時間の経過について観察すると, 投与前高値

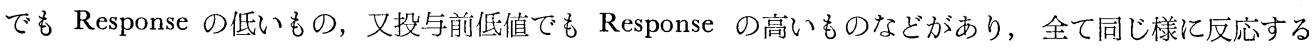
とは限らず，一般に投与前高いものほど ACTH 投与による血中 17-OHCS 值は高く，投与後 3 時間まで次 第に上昇した。乙れは AGTH-Z, AGTH 静注法にも見られることで, 本法に於いて生物学的活性が失われ たと思われる様な症例はなかった，尚 AGTH の胎児副腎に対する活賦作用であるが， Migeon et $\mathrm{al}^{70)}$.は 帝切時に ACTH 投与を行ない，母体血と臍带血の血墏中 Cortisol 比は正常分婏時と同様である事，又胎 児副腎は母体に見る様な反応がないとと等により ACTH は胎盤を通過せず，ただ母体の血中濃度に反映し たものであると述べている。 
この様な Response の高低の差異は妊娠という事がその個体にとり, 種々の Stress の附加となる為に ACTH response の異常に低いものは副腎皮質の過機能六進状態にあるか, 胎盤機能不全に陥ったものと考 えられ，重症妊娠中毒症のある妊婦の分娩時血漿 17-OHCS の下降，あるいは不変を起とす一つの大きな 要因かと思われる。

ACTH を妊婦に投与すると血申 Cortisol が増量するといわれているが，著者の成績でもそれが実証さ れ, Addison 病の患者に AGTH を投与しても Cortisol の増加は認められず, Addison 病に妊娠が合併 した場合では妊娠と同様に上昇するが，男子の Addison 病の場合 AGTH に反応していないということか ら，妊娠時に投与した ACTH は副腎以外の内分泌腺，たとえば胎盤などに作用し，Cortisol の分泌を促 したものと思われる。

Estrogen 投与に関しては正常婦人，男子に於ける文献は多く，先にも述べたが，晚期妊娠婦人に Estrogen 投与の症例はない. 弤娠月数の増加に従い Estrogen の上昇することは周知の所であり，又非妊婦及 び男子に Estrogen を投与した場合副腎機能立進状態を招来し，血漿中 17-OHCS 值の上昇を報告してい るが(1)ー73), 同時に Cortisol と結合する Protein fraction も増加し, 所謂 GBG 結合型として存在するの が大部分をなすといわれている.

私の妊娠晚期婦人に Ed. benz. $5 \mathrm{mg}$ 単独 1 回投与に於いて $12.9 \%$ \%5\%の増加を見が，去勢婦人に見る 様な増量は見られなかったが，乙れは妊娠中 Estrogen が大量に存在するため $5 \mathrm{mg}$ 程度の Estrogen では 著名な変化を起てすに致らなかったものと考えられる。

(E) 正常分晚時の母体血及び帯臍血值について

妊娠月数と共に上昇した妊婦血中 17-OHCS は分娩開始と同時に更に上昇する事が認められ，私の成績 では妊娠晚期に比べ初産婦で約 2 倍, 経産婦では 1.3 倍で, ての様な急激な上昇は母体が受ける陣痛発作の 反復が精神的，肉体的な Stress となり，一過性に副腎皮質ホルモン増加が惹起されたものと思われ，経産 婦と初産婦に於ける相違はこの Stress の差として現れて来るもので，年令，胎児の性及び体重等には関係 がない様に思われる。

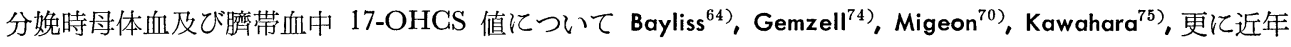
Hillman and Giroud ${ }^{76)}$ は double isotope 法を用いて測定を行なったものなど，多数の報告があるが，正常 分婏時に関しては母体血中濃度が高いというのが一致した意見であり，従来から Progesterone, Estrogen, Androgen 等, 臍帯血值が高いとする報告が多数あるのと比較すると興味ある事で，乙れらの臍帯血が低值 を示す理由は母体循環より胎児側に移行する際に胎盤の何か巧妙な作用によるものと考えられ，Migeon et

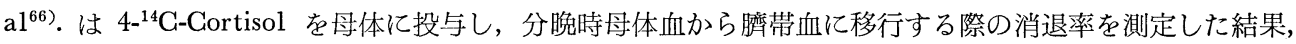
母体血值の $20 \%$ ～48\%を認めたにすぎない，又胎児から Cortisol 分泌のない事などから推測すると胎盤は Cortisol に対し Barrier として, 更に Cortisol, Gortisone の比などから 1 種の代謝藏器として存在するの ではないかと考えられる。

私の成績では経産婦，初産婦ともに臍帯血值が低く，臍帯血：母体血は前者が $37.4 \%$, 後者は $42.2 \%$ あ り, Apgar 指数とは一般に逆比例の関係にあった.

以上の如く, 血中 17-OHCS の変動は極めて delicate なものであり, 且, 巧妙に動かされているものと 考えられる.

\section{$\mathrm{V}$ 結 論}

正常婦人に於ける月経周期による血漿中 17-OHCS の変動, 去勢婦人に Estrogen, PMS-G 投与及び晚 期妊婦の ACTH responce, Estrogen 投与による変化, 更に妊娠, 分婏についての血漿 17-OHCS の変動 を Peterson et al. 法変法により測定を行なった.

〔A]健康成熟非妊婦々人の血獎中 $17-\mathrm{OHCS}$ の平均值は $12.9 \pm 2.93 \mu \mathrm{g} / \mathrm{d} 1$ で性周期による変動を認め, 月経期を除き排卵期に高值を示した. 
〔B]去勢婦人に Estrogen あるいは PMS-G 投与を行なったが， Estrogen では投与後 3 日， PMS-G で $2 \sim 3$ 日に高值を示した。

[C]正常妊娠経過については，月数の進むにつれ血獎中 17-OHCS は上昇し，分娘開始とともに著明な 上昇を示したが，乙れは CBG を共に測定したものと考えられる，又，臍帯血值は一般に母体血より低く $27.3 \%$ 66.1\%であった.

(D) 正常弤娠晚期の婦人に ACTH を投与すると投与後 3 時間で投与前の約 3 倍もの值を示した。 てれ は副腎の予備能力が妊娠晚期でも立分にあるととを示す．又 Estrogen 投与では多少の増加はあるが，非妊 婦に見られた様な增加は認められなかった。

（擱筆するに当り終始御愳篤なる御指導之御鞭样頂き，御校閲を睗つた恩師赤須文男教授に潹く感謝の意 を捧ぐると共に, 御協力, 御助言を睗つた西田助教授始め教室員の方々に対し深甚なる謝意を表します.)

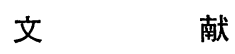

1) SELYE, H. : J. Glin. Endocrinol. 6, 117, (1946)

2）赤須文男：日産婦誌，7，655，(1955)

3) PORTER, G.C., and SILBER, R.H. : J. Biol. Chem. 185, 201, (1950)

4) NELSON, D.H. and SAMUELS, L.T. : J. Clin. Endocrinol. 12, 519, (1952) STEINBEGK, A. W. : Biochem. J. 54, 523, (1953)

5) BAYLISS, R.I.S. and NELSON, D.H. and EIK-NES, K.B. : J. Glin. Invest. 32, 818, (1953)

6) BLISS, E.L., SANDBERG, A.A., BUSGH, R.D. : J. Glin. Endocrinol. 16, 1333, (1956) 7) SILBER, R.H. and MAHONEY, J.P., FLORENTIN, A.A., GASTLE, H., BLISS, E.L. and SAMUELS, L.T. : J. Clin. Endocrinol. 16, 622, (1956) 9) PETERSON, R.H., KARRER, A. and GUERRA, S.L. : Analyt. Chem. 29, 144, (1957) 10) GOTTSGHAU, M. : Biol. Cbl. 3, 565, (1883) 11) GUIEYSSE, M.A. : Compt. rend. soc. Biol. 51, 898, (1899) 12) HEWER, E.E. : Brit. Med. J. 1, 138, (1922) 13）赤須文男：内分泌のつぼい，5，114，(1954）.

VENNING, E.H. : Endocrinol. 39 : 203, (1946)

VENNING, E.H. : J. Biol. Chem. 165 : 699, (1946) $9: 319$, (1949)

17) DEVIS, R. and LEMME

18）沢崎千秋：日産婦誌 $5: 545,(1953)$.

20）加賀山正純：日産婦誌 $7: 1955$. (1955)

22) GEMZELL, C.A. : J. Glin. Endocrinol. $13: 898$, (1953) and VOSKIAN, J. : J. Lab. Clin. Med. $46: 385$, (1955) SANDBERG, A.A. : J. Clin. Invest. 38 : 384, (1959) 17, 502, (1957) 26) VAN DER VIES, J. : Acta Endocrinol. $38: 399$, (1961)

15) HEARD, R.D.H., SOBEL, H. and 16) TOBIAN, L. : J. Glin. Endocrinol. WALLAGE, E.Z., CHRISTY, N.P. and JAILER, J.W. : J. Glin. Endocrinol. 15 : 1073, (1955) 28）渡佐富久子, 熊谷 朗 : 日内分泌誌 $32: 127,(1956)$.

29) 井林 博, 伊藤徳治, 吉田 尚 : 木と臨 5, 1161, (1957). 30）佐々木英夫, 勝又黎子, 草間光俊 : 木と臨 $9: 845,(1961)$. 31）鈴木秋悦：日内分泌誌，38:987，(1962). 32) WATANABE, T. : J. Jap. Obst \& Gyn. Soc. 8 : 29, (1961) 33) DOE, R.P., FLINK, E.B. and GOODSELL, M.G. J. Clin. Endocrinol. $16: 196,(1956)$ 34) GEMZELL, C.A. : Acta Endocrinol. $18: 342$, (1955) KOLMER, W. : Arch. ges. Physiol. $144: 361$, (1912) 36) TAKEGHI, K. : Zt. Konsist.-lehre. $12: 210,(1926)$ 37) POLL, H. : Deutsch, Med. Wschr. 567, (1933) 38) KRUMHOLZ, K.H. and MAASS, G. : Gynecologia $147: 13$, (1959) 39) PEPPER, H. and LINDSAY, S. : Proc. Soc. Exp. Biol. and Med. 104 : 145, (1960) 40) ELLISON, E.T. and BURGH, J.G. : 
Endocrinol. $10: 746$, (1936)

41) MORRELL, J.A. and HART, G.W. : Endocrinol. 29 : 796,
43) PINTO, R.M. Am. J.physiol. 45) SELYE, H., GOLLIP,
$144: 652$ ，(1945) 44）赤須文男: 臨産婦 $7: 5$, (1953).

J.B. and THOMSON, W.L. : Proc. Soc. Exp. Biol. and Med. 32 : 1377, (1955)

S.L., MEYER, R.K. and HISAW, F.L. : Endocrinol. 15 : 17, (1931)

BAER, A.J. and MACIAS, A.G. : Endocrinol. $26: 273$, (1940)

FREUDENBERGER, G.B. : Endocrinol. 25 : 585, (1939)

50) WALLAGE, E.Z. : Survey., Gynec. and Obst. $7: 433$
良, 佐藤東達: 日内分泌誌, $35: 154$, (1959).

名越和美：日産婦誌, $13: 711$, (1961). 53) WHITELEY, H.J. and STONER, H.B. : J. Endocrinol. $14: 325$, (1957) 54) DELAMARE, G. : Gited from Möllendorff, W. and Bargmann, W. Handbuch d. Mikroskop. Anatomie d. Menschen Bd. VI Teil V Springer 1954 : 730, (1904) 55) WATRIN, J. : 54) と同じ, (1925) 56) GROSSMANN, H. and SCHÖNEBERG : Zt. Geburtsh. $93: 734$, (1928) 57) ELLIOT, T.R. : J. Physiol. $44: 374$, (1913) 58) ANDERSEN, D.H. and SPERRY, W.M. : J. Physiol. $90: 269$, (1937) 59) RANDOLL, L.O. and GRAUBERD, M. : Am. J. physiol. $131: 291$, (1940)

(1953)。 61）赤須文男 : 東京医誌, $70: 247$, （1953）

60）赤須文男 : 綜合医学, $10: 330$, 62）赤須文男, 小西行男 : 綜合臨 床, $3: 1275$, (1954). 63) ROBINSON, H.J., BERNHARD, W.G., GRUBIN, H., WANNER, H., SEWEKOW, G.W. and SILBER, R.H. : J. Clin. Endocrinol. 15 : 317, (1955) 64) BAYLISS, R.I.S., BROWNE, J.G. McG., ROUND. B.P. and STEINBEGK, A.W. : Lancet 1 : 62, (1955) 65) HILlMAN, D.A., STAGHENKO, J. and GIROUD, G.J.P. : Symington and Grant : The Human Adrenal Cortex (1962) 586, E \& S Livinstone Ltd. London. 76) より引用.

66) MIGEON, G.J., BERnstrand, J., WALL, P.E. : J. Glin. Invest. 36 : 1350, (1957)

67）赤須文男：日内 分泌誌, $42: 632,(1966)$. $38: 1290,(1959)$

68) SANDBERG, A.A. and SLANW HITE, W.R. : J. Glin. Invest. (1967) 69）赤須文男, 名越和美, 早稲田健一, 柳沢和孝 : 第19回日産婦総会で発表, : J. Clin. Invest. 35 : 488, (1956) 71) PETERSON, R.E., NOKES, G., GHEN, P.S. and BLACK, R.L. : J. Glin. Endocrinol. 20 : 495, (1960) 72) WALLAGE, E.Z. and GARTER, A.C. : J. Glin. Invest. $39: 601$, (1960)

73) MUSA, R.U., SEAL, U.S. and DOE, R.P. : J. Glin. Endocrinol. 25 : 1163, (1965) 74) GEMZELL, G.A. : Acta Endocrinol. 17 : 100, (1954) 75) KAWAHARA, H. : J. Glin. Endocrinol. $18: 325$, (1958) 76) HILLMAN, D.A. and GIROUD, G.J.P. : J. Glin. Endocrinol. 25 : 243, (1965) 